\title{
Effect of low-dose gaseous ozone on pathogenic bacteria
}

\author{
Belchor Fontes ${ }^{1}$, Ana Maria Cattani Heimbecker ${ }^{2}$, Glacus de Souza Brito ${ }^{3}$, Silvia F Costa ${ }^{4}$,
} Inneke M van der Heijden ${ }^{5}$, Anna S Levin ${ }^{6 *}$ and Samir Rasslan ${ }^{7}$

\begin{abstract}
Background: Treatment of chronically infected wounds is a challenge, and bacterial environmental contamination is a growing issue in infection control. Ozone may have a role in these situations. The objective of this study was to determine whether a low dose of gaseous ozone/oxygen mixture eliminates pathogenic bacteria cultivated in Petri dishes.
\end{abstract}

Methods: A pilot study with 6 bacterial strains was made using different concentrations of ozone in an ozone-oxygen mixture to determine a minimally effective dose that completely eliminated bacterial growth. The small and apparently bactericidal gaseous dose of $20 \mu \mathrm{g} / \mathrm{mL}$ ozone/oxygen (1:99) mixture, applied for 5min under atmospheric pressure was selected. In the $2^{\text {nd }}$ phase, eight bacterial strains with well characterized resistance patterns were evaluated in vitro using agar-blood in adapted Petri dishes $\left(10^{5}\right.$ bacteria/dish). The cultures were divided into 3 groups: 1- ozone-oxygen gaseous mixture containing $20 \mu \mathrm{g}$ of $\mathrm{O}_{3} / \mathrm{mL}$ for $5 \mathrm{~min}$; 2- 100\% oxygen for 5 min; 3- baseline: no gas was used.

Results: The selected ozone dose was applied to the following eight strains: Escherichia coli, oxacillin-resistant Staphylococcus aureus, oxacillin-susceptible Staphylococcus aureus, vancomycin-resistant Enterococcus faecalis, extended-spectrum beta-lactamase-producing Klebsiella pneumoniae, carbapenem-resistant Acinetobacter baumannii, Acinetobacter baumannii susceptible only to carbapenems, and Pseudomonas aeruginosa susceptible to imipenem and meropenem. All isolates were completely inhibited by the ozone-oxygen mixture while growth occurred in the other 2 groups.

Conclusion: A single topical application by nebulization of a low ozone dose completely inhibited the growth of all potentially pathogenic bacterial strains with known resistance to antimicrobial agents.

Keywords: Ozone, Resistant bacteria, in vitro study

\section{Background}

Numerous alternatives for the treatment of chronically infected wounds have been described in the literature. The real role of various agents, topically applied, remains undetermined [1-3].Topical application of antibiotics has shown limited efficacy in the management of infected wounds, without conclusive results $[4,5]$. In the last several years, various in vitro and in vivo experimental and clinical studies have investigated the bactericidal effect of the topical application of ozone in different

\footnotetext{
* Correspondence: gcih.adm@hc.fm.usp.br

${ }^{6}$ Departments of Infectious Diseases and Nosocomial Infection Control and LIM54, University of São Paulo, Rua Banibas, 618, São Paulo, SP 05460-010, Brazil

Full list of author information is available at the end of the article
}

situations, including the management of infected wounds [6-8]. $\mathrm{O}_{3}$ is a potent oxidant and an important disinfectant, acting on microorganisms by means of oxidation of their biological material [9]. It has been reported that $\mathrm{O}_{3}$ can be employed as a bactericidal agent under various forms, such as ozonized saline solution [10], ozonized water [11], ozonized oil [7], ozone associated with other substances [12], and more frequently the gaseous $\mathrm{O}_{3} / \mathrm{O}_{2}$ mixture [13]. The topical use of $\mathrm{O}_{3}$ has also been reported for environment decontamination in diverse situations: in agriculture for food decontamination [14], in odontology [15], and in clinical settings such as in the treatment of infected wounds [7]. Gaseous ozone has also been potentially considered for the

\section{Biomed Central}

(c) 2012 Fontes et al.; licensee BioMed Central Ltd. This is an Open Access article distributed under the terms of the Creative Commons Attribution License (http://creativecommons.org/licenses/by/2.0), which permits unrestricted use, distribution, and reproduction in any medium, provided the original work is properly cited. 
disinfection of the hospital environment, which can be a source of microorganisms for patients [16]. However, a minimal effective antibacterial dose of gaseous ozone for topical application has not been clearly determined [17].

The objective of this study was to determine whether a low dose of $\mathrm{O}_{3}$, in a gaseous $\mathrm{O}_{3} / \mathrm{O}_{2}$ mixture, applied to Petri dishes containing bacterial culture completely eliminates the growth of different bacterial strains. The strains chosen in this study were those that were important pathogens of nosocomial and community-acquired infections and those with known mechanisms of antimicrobial resistance.

\section{Methods}

This study was performed at the $3^{\text {rd }}$ Division of Clinical Surgery and Laboratory of Medical Investigation (LIM54 and 62), of the Hospital das Clínicas of the University of São Paulo School of Medicine. The project was approved by the Ethics Committee of the Institution.

For bacterial culture, Petri dishes $(90 \mathrm{~mm}$ internal diameter) were adapted with the addition of two special tips in order to allow continuous gas entry and exit

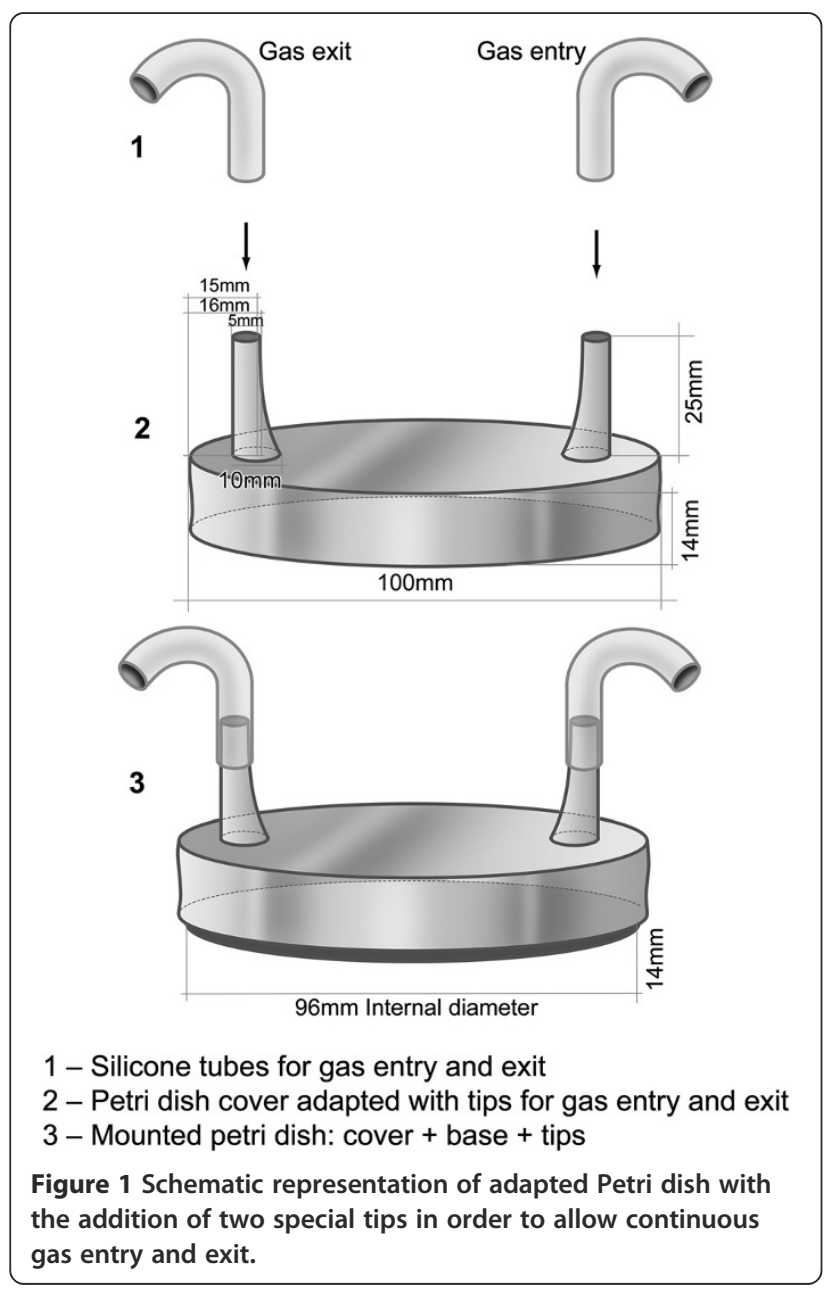

(Figure 1). The study was done in two phases: a pilot test ( $1^{\text {st }}$ phase) to determine the dose of $\mathrm{O}_{3} / \mathrm{O}_{2}$ to be later employed in the evaluation of its bactericidal activity when applied to different bacterial strains ( $2^{\text {nd }}$ phase). In both phases, bacterial strains were inoculated on agarblood in the adapted Petri dishes, at a concentration of $10^{5}$ bacteria/dish. Ozone gas was produced from medicinal oxygen (liquid oxygen with a degree of purity of $98 \%$ ) by means of a medicinal $\mathrm{O}_{3}$ generator provided by the Gas Department of the Aircraft Technology Institute (Instituto de Tecnologia da Aeronáutica - ITA, Brazilian Army, São José dos Campos, Brazil). This instrument was equipped with an oxygen flow controller (MKS Type $1179^{\mathrm{a}}$ ) with $0.01 \mathrm{~min}$ precision, in which a controlled oxygen flow passes through a glass cylinder and is exposed to an electric discharge by a dielectric barrier with controlled potency and voltage (Figure 2). The electric discharge generates $\mathrm{O}_{3}$ and its concentration can be measured. The final product is a gaseous $\mathrm{O}_{3} / \mathrm{O}_{2}$ mixture, in which the concentration is regulated by variation of oxygen flow and the voltage applied to the electrodes.

\section{First phase (pilot test)}

In this phase, Escherichia coli - ATCC:35218, Staphylococcus aureus susceptible to oxacillin - ATCC:25923, and Pseudomonas aeruginosa susceptible to imipenem and meropenem - ATCC:27853 were inoculated on agar-blood in Petri dishes and incubated aerobically at $35 \pm 2^{\circ} \mathrm{C}$ for 18 to 24 hours. A standardized inoculum was prepared using the direct colony suspension by making a saline suspension of isolated colonies selected from blood agar plates. Each bacterial suspension was adjusted to 0.5 McFarland turbidity standard (1 to $2 \mathrm{x}$ $10^{8} \mathrm{CFU} / \mathrm{mL}$ ) using a photometric device (colorimeter

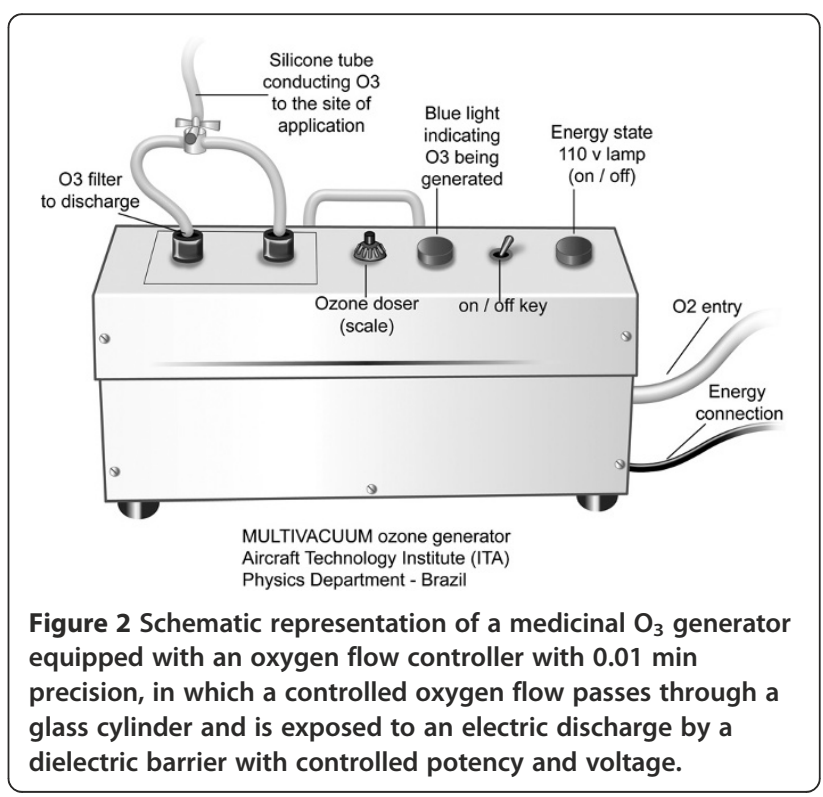


Vitek ${ }^{\circledR} 1$, BioMérieux, Etoile, France). The 0.5 McFarland suspension was diluted 1:1000 in sterile saline, resulting in a tube containing approximately $10^{5} \mathrm{CFU} / \mathrm{mL}$. An aliquot of $10 \mu \mathrm{L}$ of this suspension was inoculated in another blood agar plate (final concentration of $10^{3} \mathrm{CFU} / \mathrm{mL}$ ). Then the dishes were then subjected to decreasing doses of $\mathrm{O}_{3}$, starting with $100 \mu \mathrm{g} / \mathrm{mL}$. Initially, the plates were exposed for $60 \mathrm{~min}$. The time and the dose were subsequently decreased. The minimal dose and time required to completely prevent bacterial growth of the three microorganisms was determined $(20 \mu \mathrm{g} / \mathrm{mL}$ for $5 \mathrm{~min}) . \mathrm{O}_{3}$ was then applied at the dose of $15 \mu \mathrm{g} / \mathrm{mL}$ for $5 \mathrm{~min}$ to six bacterial isolates (Escherichia coli - ATCC: 25922; Staphylococcus aureus resistant to oxacillin ATCC:29213; Staphylococcus aureus susceptible to oxacillin - ATCC:25923; Enterococcus faecalis resistant to vancomycin - ATCC:51299; Klebsiella pneumoniae ESBL-producer, susceptible only to carbapenems - clinical isolate from a patient, obtained as part of standard clinical care; and Pseudomonas aeruginosa - susceptible to imipenem and meropenem - ATCC:27853). The experiment was repeated four times for each microorganism, and the effects were evaluated.

\section{Second phase}

For this phase of the study, eight potentially pathogenic bacteria strains were included, comprising the six employed in the first phase plus Acinetobacter baumannii susceptible only to carbapenem - ATCC:19606 and Acinetobacter baumannii resistant to carbapenem clinical isolate from a patient, obtained as part of standard clinical care. Each strain was inoculated on agar-blood in four Petri dishes, and the colony forming units (CFUs) were counted at $24 \mathrm{~h}$ and $48 \mathrm{~h}$ following the treatment applied to each group. Three study groups were employed: the experimental group treated with $1 \% \mathrm{O}_{3} / 99 \% \mathrm{O}_{2}$ gas, corresponding to $20 \mu \mathrm{g}$ of $\mathrm{O}_{3} / \mathrm{mL}$ $\left(\mathrm{O}_{3}\right.$-group $)$; and two control groups, including one treated with $100 \%$ oxygen $\left(\mathrm{O}_{2}\right.$-group), and one called the Baseline group in which no gas was used.
Each bacterial strain was inoculated into four adapted Petri dishes, and $10 \mathrm{~min}$ later each dish (except for the Baseline group) received gas nebulization for $5 \mathrm{~min}$, under atmospheric pressure. Thereafter, each dish was incubated at $37^{\circ} \mathrm{C}$ for $48 \mathrm{~h}$. Colony counts were performed $24 \mathrm{~h}$ and $48 \mathrm{~h}$ following inoculation.

Statistical analysis of the results was performed using the Mann-Whitney Test to compare the global results obtained for the $\mathrm{O}_{2}$-group with those of the Baseline group after 24 and $48 \mathrm{~h}$. The Kruskal-Wallis test was employed to compare the CFU counts of each bacterial strain with those of other strains, either within the same group, or of other groups. A p value $<0.05 \%$ was considered significant.

\section{Results}

\section{Pilot study}

The initial tests with the E. coli, S. aureus, and P. aeruginosa strains demonstrated that doses greater than or equal to $20 \mu \mathrm{g}$ of $\mathrm{O}_{3} / \mathrm{mL}$ for 5 min totally prevented the growth of these three bacterial strains. However when $15 \mu \mathrm{g}$ of $\mathrm{O}_{3} / \mathrm{mL}$ was applied for $5 \mathrm{~min}$ and the effect was evaluated on six bacterial strains, a low number of CFUs were present $48 \mathrm{~h}$ after inoculation for two of the six tested strains (Table 1). Therefore, $20 \mu \mathrm{g}$ of $\mathrm{O}_{3} / \mathrm{mL}$ in the $\mathrm{O}_{3} / \mathrm{O}_{2}$ gaseous mixture for $5 \mathrm{~min}$ was chosen as the dose for the $2^{\text {nd }}$ phase.

\section{Second phase}

The results are expressed as bacterial strain CFUs per experiment. All experiments for the $\mathrm{O}_{3}$-group showed complete inhibition of bacterial growth for all strains at $24 \mathrm{~h}$ and $48 \mathrm{~h}$. This was statistically significant when comparing $\mathrm{O}_{3}$-group with each other group $(\mathrm{p}<0.014$ for each bacterial strain). No difference in bacterial counts (p: 0.80) was noticed between the other two groups (Table 2). In Baseline and $\mathrm{O}_{2}$-groups, Acinetobacter baumannii resistant to carbapenems, presented CFU counts at $24 \mathrm{~h}$ and $48 \mathrm{~h}$ significantly greater $(p<0.05)$ than all those of the other strains, except Enterococcus faecalis.

Table 1 Bacterial isolates submitted to an $\mathrm{O}_{3} / \mathrm{O}_{2}$ gaseous mixture to determine the effect on the in vitro growth of bacteria

\begin{tabular}{|c|c|c|c|c|}
\hline \multirow[t]{2}{*}{ Bacterial strains exposed to $15 \mu \mathrm{g} / \mathrm{mL}$ of $\mathrm{O}_{3}$ (in a $\mathrm{O}_{3} / \mathrm{O}_{2}$ gaseous mixture $-1 \% / 99 \%$ ) for $5 \mathrm{~min}$} & \multicolumn{4}{|c|}{ Growth at 48 hours (CFU) } \\
\hline & P1 & $\mathbf{P 2}$ & P3 & P4 \\
\hline 1= Escherichia coli - ATCC: 25922 & 0 & 0 & 0 & 0 \\
\hline $2=$ Staphylococcus aureus resistant to oxacillin -ATCC:29213 & 5 & 0 & 0 & 0 \\
\hline $3=$ Staphylococcus aureus susceptible to oxacillin - ATCC:25923 & 0 & 0 & 0 & 0 \\
\hline 4= Enterococcus faecalis resistant to vancomycin - ATCC:51299 & 0 & 0 & 0 & 0 \\
\hline $5=$ Klebsiella pneumoniae - ESBL-producer, susceptible only to carbapenems - Clinical isolate from a patient & 0 & 0 & 0 & 0 \\
\hline $6=$ Pseudomonas aeruginosa - susceptible to imipenem and meropenem - ATCC:27853 & 9 & 1 & 0 & 0 \\
\hline
\end{tabular}


Table 2 Bacterial in vitro growth, at 24 hours and 48 hours, of isolates submitted to an $\mathrm{O}_{3} / \mathrm{O}_{2}$ gaseous mixture $\left(\mathrm{O}_{3}\right.$ group), to $100 \% \mathrm{O}_{2}\left(\mathrm{O}_{2}\right.$ group) and not submitted to gas treatment (Baseline group)

\begin{tabular}{|c|c|c|c|c|c|c|c|c|c|c|c|c|c|}
\hline \multirow[t]{4}{*}{ Bacterial strains } & \multirow{4}{*}{$\begin{array}{l}\text { Culture } \\
\text { duration }\end{array}$} & \multicolumn{12}{|c|}{ CFU / dish } \\
\hline & & \multirow{2}{*}{\multicolumn{4}{|c|}{$\begin{array}{l}\mathrm{O}_{3} \text { Group } \\
\text { Plates }(\mathrm{P})\end{array}$}} & \multirow{2}{*}{\multicolumn{4}{|c|}{$\frac{\mathrm{O}_{2} \text { Group }}{\text { Plates }(\mathrm{P})}$}} & \multirow{2}{*}{\multicolumn{4}{|c|}{$\begin{array}{l}\text { Baseline Group } \\
\text { Plates }(\mathrm{P})\end{array}$}} \\
\hline & & & & & & & & & & & & & \\
\hline & & $\mathrm{P1}$ & P2 & P3 & $\mathrm{P4}$ & P1 & P2 & P3 & P4 & $\mathrm{P1}$ & P2 & P3 & P4 \\
\hline \multirow[t]{2}{*}{$1=$ Escherichia coli - ATCC:25922 } & $24 \mathrm{~h}$ & 0 & 0 & 0 & 0 & 83 & 68 & 59 & 73 & 58 & 66 & 65 & 76 \\
\hline & $48 \mathrm{~h}$ & 0 & 0 & 0 & 0 & 78 & 69 & 58 & 61 & 57 & 68 & 62 & 80 \\
\hline \multirow[t]{2}{*}{$2=$ Staphylococcus aureus resistant to oxacillin -ATCC:29213 } & $24 \mathrm{~h}$ & 0 & 0 & 0 & 0 & 94 & 81 & 80 & 55 & 98 & 83 & 104 & 95 \\
\hline & $48 \mathrm{~h}$ & 0 & 0 & 0 & 0 & 88 & 74 & 85 & 49 & 75 & 89 & 104 & 90 \\
\hline \multirow[t]{2}{*}{$3=$ Staphylococcus aureus susceptible to oxacillin - ATCC:25923 } & $24 \mathrm{~h}$ & 0 & 0 & 0 & 0 & 72 & 45 & 82 & 68 & 65 & 44 & 91 & 76 \\
\hline & $48 \mathrm{~h}$ & 0 & 0 & 0 & 0 & 70 & 47 & 75 & 69 & 66 & 39 & 94 & 73 \\
\hline \multirow[t]{2}{*}{ 4= Enterococcus faecalis resistant to vancomycin - ATCC: 51299} & $24 \mathrm{~h}$ & 0 & 0 & 0 & 0 & 69 & 64 & 201 & 75 & 73 & 100 & 105 & 71 \\
\hline & $48 \mathrm{~h}$ & 0 & 0 & 0 & 0 & 79 & 78 & 207 & 82 & 68 & 97 & 106 & 57 \\
\hline \multirow{2}{*}{$\begin{array}{l}\text { 5= ESBL producing Klebsiella pneumoniae susceptible only to } \\
\text { carbapenems - clinical isolate from a patient. }\end{array}$} & $24 \mathrm{~h}$ & 0 & 0 & 0 & 0 & 65 & 75 & 153 & 71 & 87 & 113 & 117 & 80 \\
\hline & $48 \mathrm{~h}$ & 0 & 0 & 0 & 0 & 68 & 81 & 135 & 69 & 96 & 88 & 108 & 80 \\
\hline \multirow{2}{*}{$\begin{array}{l}6=\text { Acinetobacter baumannii resistant to carbapenem - clinical } \\
\text { isolate from a patient. }\end{array}$} & $24 \mathrm{~h}$ & 0 & 0 & 0 & 0 & 226 & 205 & 201 & 162 & 158 & 165 & 159 & 206 \\
\hline & $48 \mathrm{~h}$ & 0 & 0 & 0 & 0 & 214 & 196 & 171 & 137 & 135 & 162 & 130 & 185 \\
\hline \multirow{2}{*}{$\begin{array}{l}7=\text { Acinetobacter baumannii susceptible only to } \\
\text { carbapenem - ATCC:19606 }\end{array}$} & $24 \mathrm{~h}$ & 0 & 0 & 0 & 0 & 70 & 60 & 58 & 70 & 63 & 65 & 63 & 67 \\
\hline & $48 \mathrm{~h}$ & 0 & 0 & 0 & 0 & 69 & 61 & 52 & 63 & 65 & 69 & 62 & 64 \\
\hline \multirow{2}{*}{$\begin{array}{l}8=\text { Pseudomonas aeruginosa susceptible to imipenem } \\
\text { and meropenem-ATCC:27853 }\end{array}$} & $24 \mathrm{~h}$ & 0 & 0 & 0 & 0 & 155 & 68 & 138 & 94 & 82 & 85 & 88 & 65 \\
\hline & $48 \mathrm{~h}$ & 0 & 0 & 0 & 0 & 110 & 79 & 97 & 94 & 83 & 72 & 66 & 69 \\
\hline
\end{tabular}

ESBL: Extended-spectrum beta-lactamase; CFU: Colony-forming units; each experiment was repeated 4 times (Plates: P1 to P4).

For each bacterial strain, no significant difference was observed in CFU counts at $24 \mathrm{~h}$ compared to that at $48 \mathrm{~h}$.

\section{Discussion}

The eight bacterial strains employed in this study were selected to represent pathogenic bacteria commonly present in patients with severe nosocomial infections, with known resistance to antibiotics. Our results showed that the application of a low dose of gaseous ozone completely prevented the in vitro growth of all bacterial strains. On the other hand, in both control groups, bacterial growth occurred in all eight bacterial strains and treatment with $100 \% \mathrm{O}_{2}$ had no effect on bacterial proliferation, compared with the Baseline group.

In the 1960s, Scott et al., using topical application of ozonized saline, showed that approximately $2 \times 10^{7}$ molecules of $\mathrm{O}_{3}$ per bacterium provoked $50 \%$ death [10]. They attributed this to $\mathrm{O}_{3}$ reacting with lipid double bonds, thus leading to bacterial wall lysis and bacterial cell content extravasation [10]. By entering the cell, $\mathrm{O}_{3}$ promotes oxidation of nucleic and amino acids; and cell lysis depends on the extent of these reactions [1].

The culture medium employed in this study was agarblood in Petri dishes. The use of agar for bacterial culture in Petri dishes is usual practice in microbiology, including the evaluation of bactericidal effects of different substances, such as ozone. An in vitro study aiming at decontamination with prolonged $(4 \mathrm{~h})$ application of gaseous $\mathrm{O}_{3}(2 \mathrm{ppm})$, revealed a reduction of viability of various bacteria, such as E. coli, S. aureus, Serratia liquefaciens, and Listeria innocula, suggesting a disinfectant effect of $\mathrm{O}_{3}$. The bacteria were cultured on agar in Petri dishes as well as in other culture media, and the author considered agar as the best culture media for measuring the efficacy of $\mathrm{O}_{3}$ [14].

Pereira et al. reported that application of a gaseous $\mathrm{O}_{3} / \mathrm{O}_{2}$ mixture $(0.4 \% / 99.6 \%)$ for $1 \mathrm{~h}$, at constant pressure and flow (11 $\mathrm{mm} \mathrm{Hg}$ and $2 \mathrm{~L} / \mathrm{min}$, respectively) and controlled temperature, in plates containing $10^{4} \mathrm{CFU} / \mathrm{mL}$ of $E$. coli, S. aureus, and $P$. aeruginosa led to total inhibition of growth of these bacteria [18]. Compared to this study, the $\mathrm{O}_{3}$ concentration in the gaseous $\mathrm{O}_{3} / \mathrm{O}_{2}$ mixture in the present study was 2.5 times greater, the duration of application was much shorter (1/12), and the gas flow was half $(1 \mathrm{~L} / \mathrm{min})$. Furthermore, in the present study, potentially pathogenic bacteria with higher inoculums and known antimicrobial resistance were selected. Due to these differences, comparison of these studies is not viable. Other in vitro studies involving gaseous ozone have been performed but cannot be compared with our study as they involve Thichophyton spp. [19], mutans streptococci [20] and Listeria innocua [21].

The potential of our findings is interesting. The hospital environment has been increasing implicated in the transmission of resistant bacteria such as methicillin- 
resistant S. aureus and enterococci [22,23]. Environmental cleaning and the application of hydrogen peroxide in the environment have recently deserved attention $[24,25]$ and ozone may have a similar use. In 1973, Broadwater et al. determined the minimum dose of $\mathrm{O}_{3}$ dissolved in water (ozonized water) needed to eliminate the growth of three bacterial species when applied for $5 \mathrm{~min}$. They observed that $0.12 \mathrm{mg} / \mathrm{L}$ of ozone was lethal for Bacillus cereus; and that $0.19 \mathrm{mg} / \mathrm{L}$ was lethal for Bacillus megaterium and E. coli [11]. Although $\mathrm{O}_{3}$ dissolved in water was employed for surface decontamination, there was no clear definition of a minimum effective dose for its application. Likewise, there is no clear dose for $\mathrm{O}_{3}$ in the form of an aerosol $\left(\mathrm{O}_{3}\right.$ dissolved in air) to be employed for surface decontamination of scientific instruments [26,27]. Also focusing on environment decontamination, $\mathrm{Li}$ analyzed the resistance of various bacteria exposed to $\mathrm{O}_{3}$ for surface disinfection, and pointed out the importance of the species $(E$. coli was more susceptible) and of the $\mathrm{O}_{3}$ dose (concentration $\times$ time of exposure) on resistance to $\mathrm{O}_{3}{ }^{29}$. In the present study the dose of $\mathrm{O}_{3}$ employed totally prevented the growth of all bacterial strains although Acinetobacter baumannii had a greater inoculum than the other bacterial strains. A concern involving the use of environmental $\mathrm{O}_{3}$ for environmental disinfection is its toxicity, especially to the lungs [28] as the epithelial lining fluid has a relatively poor antioxidant capacity when compared with the blood. To enable the use of ozone in the hospital environment, exposure of patients and healthcare workers to inhalation would have to be avoided.

Another potential use for ozone is in the treatment of infected wounds. A clinical study reported that in the case of superficial wounds with antibiotic resistant sepsis following trauma and surgery, the application of $\mathrm{O}_{3} / \mathrm{O}_{2}$ resulted in wound healing and control of sepsis [8]. Sanchez et al. reported the efficient management of diabetic foot with gaseous $\mathrm{O}_{3} / \mathrm{O}_{2}$ application [29]. In a clinical prospective study [30], 61 patients with "diabetic foot" infections were randomized into two groups: topical gaseous $\mathrm{O}_{3}$ application $(80 \mu / \mathrm{mL}$ maintained during $20 \mathrm{~min} /$ session) + conventional (debridement + wound dressing) vs placebo $\left(\mathrm{O}_{2}\right.$ treatment). Although in the whole population the wound closure in the ozone group vs placebo (41\% vs $33 \%$ ) was not significant, it was observed that in the 34 patients who completed the study (16 of $\mathrm{O}_{3}$ and 18 placebo) the wound closure was significantly higher in the $\mathrm{O}_{3}$ group ( $81 \%$ vs $44 \%$ ); and for patients with wounds $\leq 5 \mathrm{~cm}^{2}$ the total closure was higher in the $\mathrm{O}_{3}$ group when compared with placebo $(100 \%$ vs $50 \% ; \mathrm{p}=0.006$ ). This suggested that $\mathrm{O}_{3}$ was superior to conventional treatment. However it is difficult to draw conclusions from such a small study. A point of concern is the toxicity of ozone to the skin. The skin is protected against oxidative stress by a variety of antioxidants [31], but chronic exposure to $\mathrm{O}_{3}$ can be deleterious to the skin, especially to the stratum corneum, leading to a cascade of effects in the deeper layers. Brief topical exposures of $\mathrm{O}_{3}$, however, have been shown to be non-toxic [31].

Our study presents the following limitations: it is a preliminary evaluation and focuses on the in vitro effect of a minimal dose of ozone applied in Petri dishes containing bacteria seeded superficially on the Agar medium. It is not yet clear how well our findings may translate into clinical practice in which factors such as variable blood flow, with ischemia, necrotic tissue and high bacterial burdens may play an important role, especially in the diabetic foot.

\section{Conclusions}

In conclusion, the results of the present in vitro study showed that a dose of $20 \mu \mathrm{g}$ of $\mathrm{O}_{3} / \mathrm{mL}$ in a gaseous $\mathrm{O}_{3} /$ $\mathrm{O}_{2}$ mixture $\left(1 \% \mathrm{O}_{3} / 99 \% \mathrm{O}_{2}\right)$, in a single topical application by nebulization for 5 min under atmospheric pressure, effectively inhibited the growth of all potentially pathogenic bacterial strains with known antimicrobial resistance.

\section{Competing interests}

None of the authors have competing interests concerning this study.

\section{Authors' contributions}

Belchor Fontes- study design, analysis of data, and writing of manuscript. Ana Maria Cattani Heimbecker- laboratory work. Glacus de Souza Britoconception of study. Silvia F. Costa- laboratory supervision. Inneke M. van der Heijden- laboratory work. Anna S. Levin- analysis of data, critical review of manuscript. Samir Rasslan: final approval of the manuscript. All authors read and approved the final manuscript.

\section{Funding}

This study did not receive external funding.

\section{Author details}

${ }^{1} 3$ rd Division of Clinical Surgery and Laboratory of Medical Investigation (LIM-62), Hospital das Clínicas, University of São Paulo, São Paulo, Brazil. ${ }^{2}$ Laboratory of Medical Investigation (LIM-62), Hospital das Clínicas, University of São Paulo, São Paulo, Brazil. ${ }^{3}$ Clinical Immunology and Allergy Division, Hospital das Clínicas, University of São Paulo, São Paulo, Brazil. ${ }^{4}$ Department of Infectious Diseases and LIM54, University of São Paulo, São Paulo, Brazil. ${ }^{5}$ Laboratory of Medical Investigation (LIM-54), Hospital das Clínicas, University of São Paulo, São Paulo, Brazil. 'Departments of Infectious Diseases and Nosocomial Infection Control and LIM54, University of São Paulo, Rua Banibas, 618, São Paulo, SP 05460-010, Brazil. Department of Surgery, University of São Paulo, São Paulo, Brazil.

Received: 10 July 2012 Accepted: 15 November 2012 Published: 18 December 2012

\section{References}

1. Atiyeh BS, Dibo SA, Hayek SN: Wound cleansing, topical antiseptics and wound healing. In Wound J 2009, 6:420-430.

2. Bikowski J: Secondarily infected wounds and dermatoses: a diagnosis and treatment guide. J Emerg Med 1999, 17:197-206.

3. Lipsky BA, Hoey C: Topical antimicrobial therapy for treating chronic wounds. Clin Infec Dis 2009, 49:1541-1549.

4. Reimer K, Fleischer W, Brögmann B, Schreier H, Burkhard P, Lanzendörfer A, Gümbel H, Hoekstra H, Behrens-Baumann W: Povidone-iodine liposomes - an overview. Dermatology 1997, 195:93-99. 
5. Lochman P, Plodr M, Páral J, Smejkal K: Nanofiber micro-dispersed oxidized cellulose as a carrier for topical antimicrobials: first experience. Surg Infect 2010, 11:29-32.

6. Steinhart H, Schulz S, Mutters R: Evaluation of ozonated oxygen in an experimental animal model of osteomyelitis as a further treatment option for skull-base osteomyelitis. Eur Arch Otorhinolaryngol 1999, 256:153-157.

7. Kim HS, Noh SU, Han YW, Kim KM, Kang H, Kim HO, Park YM: Therapeutic effects of topical application of ozone on acute cutaneous wound healing. J Korean Medical Sci 2009, 24:368-374.

8. Białoszewski D, Kowalewski M: Superficially, longer, intermittent ozone therapy in the treatment of the chronic, infected wounds. Ortop Traumatol Rehabil 2003, 5:652-658.

9. Mehlman MA, Borek C: Toxicity and biochemical mechanisms of ozone. Environ Res 1987, 42:36-53.

10. Scott DBM, Lesher EC: Effect of ozone on survival and permeability of Escherichia coli. J Bacteriol 1963, 85:567-576.

11. Broadwater WT, Hoehn RC, King PH: Sensivity of three selected bacterial species to ozone. Applied Microbiol 1973, 26:391-393.

12. Dmitrieva NA, Zyrianova NV, Grigor'ian AS, Vasilishina SI: Microflora dynamics in purulent skin wound in rats after ozonized perftorane applications. Stomatologiia (Mosk) 2009, 88:14-16.

13. Aydogan A, Gurol MD: Application of gaseous ozone for inactivation of Bacillus subtilis spores. J Air Waste Manag Assoc 2006, 56:179-185.

14. Moore G, Griffith C, Peters A: Bactericidal properties of ozone and its potential application as a terminal disinfectant. J Food Prot 2000, 63:1100-1106.

15. Johansson E, Claesson R, van Dijken JW: Antibacterial effect of ozone on cariogenic bacterial species. J Dent 2009, 37:449-453.

16. Davies A, Pottage T, Bennett A, Walker J: Gaseous and air decontamination technologies for Clostridium difficile in the healthcare environment. J Hosp Infect 2011, 77:199-203.

17. Gurley B: Ozone: pharmaceutical sterilant of the future? J Parenteral SC Technol 1985, 39:256-261.

18. Pereira MMS, Navarini IIA, Lýcia MJ, Pacheco AM Jr, Silva RA: Effect of different gases on bacterial growth. Experimental study "in vitro". Rev Col Bras Cir 2005, 32:1. online.

19. Aditya KG, William B: Ozone gas effectively kills laboratory strains of Trichophyton rubrum and Trichophyton mentagrophytes using an in vitro test system. J Dermatolog Treat 2012, in press.

20. Castillo A, Galindo-Moreno P, Avila G, Valderrama M, Liébana J, Baca P: In vitro reduction of mutans streptococci by means of ozone gas application. Quintessence Int 2008, 39:827-831.

21. Fan L, Song J, McRae KB, Walker BA, Sharpe D: Gaseous ozone treatment inactivates Listeria innocua in vitro. J Appl Microbiol 2007, 103:2657-2663.

22. Boyce JM: Environmental contamination makes an important contribution to hospital infection. J Hosp Infect 2007, 65(Suppl 2):50-54.

23. Byrns $G$, Fuller TP: The risks and benefits of chemical fumigation in the health care environment. J Occupat Environm Hyg 2011 8:104-112.

24. Andersen BM, Rasch M, Hochlin K, Jensen F-H, Wismar P, Fredriksen J-E: Decontamination of rooms, medical equipment and ambulances using an aerosol of hydrogen peroxide disinfectant. J Hosp Infect 2006, 62:149-155.

25. Boyce JM: New approaches to decontamination of rooms after patients are discharged. Infect Control Hosp Epidemiol 2009, 30:515-17.

26. Kowalski WJ, Bahnfleth WP, Striebig BA, Whittam TS: Demonstration of a hermetic airborne ozone disinfection system: studies on E. coli. AlHA 2003, 64:222-227.

27. Moat J, Cargill J, Shone J, Upton M: Application of a novel decontamination process using gaseous ozone. Can J Microbiol 2009, 55:928-933.

28. Bocci $\mathrm{V}$ : Is it true that ozone is always toxic? The end of a dogma Toxicol Appl Pharmacol 2006, 216:493-504

29. Martínez-Sánchez G, Al-Dalain SM, Menéndez S, Re L, Giuliani A, Candelario-Jalil E, Alvarez H, Fernández-Montequín Jl, León OS: Therapeutic efficacy of ozone in patients with diabetic foot. Eur J Pharmacol 2005, 523:151-161.
30. Wainstein J, Feldbrin Z, Boaz M, Harman-Boehm I: Efficacy of ozone-oxygen therapy for the treatment of diabetic foot ulcers. Diabetes Technol Ther 2011, 13:1255-1260.

31. Valacchi G, Fortino V, Bocci V: The dual action of ozone on the skin. Brit J Derm 2005, 153:1096-1100.

doi:10.1186/1471-2334-12-358

Cite this article as: Fontes et al:: Effect of low-dose gaseous ozone on pathogenic bacteria. BMC Infectious Diseases 2012 12:358.

\section{Submit your next manuscript to BioMed Central and take full advantage of:}

- Convenient online submission

- Thorough peer review

- No space constraints or color figure charges

- Immediate publication on acceptance

- Inclusion in PubMed, CAS, Scopus and Google Scholar

- Research which is freely available for redistribution 